\title{
UJI EFEKTIFITAS KOMBINASI PUPUK ORGANONITROFOS DAN PUPUK ANORGANIK TERHADAP PERTUMBUHAN, PRODUKSI, DAN SERAPAN HARA TANAMAN UBI KAYU (Manihot esculenta Crantz) PADA MUSIM TANAM KETIGA DI GEDUNG MENENG
}

\author{
Dwika Putri Suri'), Jamalam Lumbanraja $^{2)}$, Hery Novpriansyah ${ }^{2)}$, Dermiyati2) \\ ${ }^{1}$ Mahasiswa Jurusan Agroteknologi Fakultas Pertanian Universitas Lampung \\ ${ }^{2}$ Dosen Jurusan Agroteknologi Fakultas Pertannian Universitas Lampung \\ Jln. Prof. Dr. Soemantri Brojonegoro No. 1 Bandar Lampung 35145 \\ Email:Dwikaputri20@gmail.com
}

\begin{abstract}
ABSTRAK
Ubi kayu dikenal sebagai tanaman yang memiliki daya adaptasi yang kuat sehingga sangat potensial dibudidayakan di lahan marginal. Penelitian ini bertujuan untuk menguji keefektifan pupuk Organonitrofos dan kombinasinya dengan pupuk kimia, serta menetapkan dosis terbaik dari kombinasi pupuk Organonitrofos dengan pupuk kimia terhadap pertumbuhan, serapan hara, dan produksi tanaman ubikayu pada musim tanam ketiga. Penelitian lapang dilaksanakan di LaboratoriumLapangTerpadu Universitas Lampung pada bulan November 2014 hingga Agustus 2015. Penelitian ini dilakukan dengan Rancangan Acak Lengkap (RAL) yang terdiri dari 6 perlakuan yaitu T1 (kontrol), T2 (urea $200 \mathrm{~kg} \mathrm{ha}^{-1}, \mathrm{SP} 36300 \mathrm{~kg} \mathrm{ha}^{-1}, \mathrm{KCl} 400 \mathrm{~kg} \mathrm{ha}^{-1}$ ), T3 (urea $150 \mathrm{~kg} \mathrm{ha}^{-1}, \mathrm{SP} 36100$ $\mathrm{kg} \mathrm{ha}^{-1}, \mathrm{KCl} 300 \mathrm{~kg} \mathrm{ha}^{-1}$, Organonitrofos $500 \mathrm{~kg} \mathrm{ha}^{-1}$ ), T4 (urea $100 \mathrm{~kg} \mathrm{ha}^{-1}, \mathrm{SP} 36100 \mathrm{~kg} \mathrm{ha}^{-1}, \mathrm{KCl} 200 \mathrm{~kg}$ $\mathrm{ha}^{-1}$, Organonitrofos $1.000 \mathrm{~kg} \mathrm{ha}^{-1}$ ), T5 (urea $50 \mathrm{~kg} \mathrm{ha}^{-1}$, SP36 $50 \mathrm{~kg} \mathrm{ha}^{-1}, \mathrm{KCl} 200 \mathrm{~kg} \mathrm{ha}^{-1}$, Organonitrofos $2.000 \mathrm{~kg} \mathrm{ha}^{-1}$ ), dan T6 (Organonitrofos $5.000 \mathrm{~kg} \mathrm{ha}^{-1}$ ) dengan 3 ulangan.Hasil penelitian menunjukan bahwa perlakuan urea $100 \mathrm{~kg} \mathrm{ha}^{-1}, \mathrm{SP} 36100 \mathrm{~kg} \mathrm{ha}^{-1}, \mathrm{KCl} 200 \mathrm{~kg} \mathrm{ha}^{-1}$, Organonitrofos $1.000 \mathrm{~kg} \mathrm{ha}^{-1}$ menghasilkan produksi (bobot umbi), dan panen hara N, P, K, dan C-organik tanaman ubikayu lebih tinggi dibandingkan perlakuan kombinasi lainnya. Sedangkan pupuk anorganik dengan dosis urea $200 \mathrm{~kg} \mathrm{ha}^{-1}, \mathrm{SP} 36300 \mathrm{~kg} \mathrm{ha}^{-1}$, $\mathrm{KCl} 400 \mathrm{~kg} \mathrm{ha}^{-1}$ menghasilkan tinggi tanaman tertinggi dibandingkan perlakuan kombinasi lainnya.
\end{abstract}

Kata kunci: Kombinasi pupuk, Organonitrofos, Pemupukan, Produksi ubikayu, Serapan hara, Tanahultisol,Ubikayu.

\section{PENDAHULUAN}

Di Indonesia, ubikayu merupakan makanan pokok ke-tiga setelah padi dan jagung. Ubikayu merupakan salah satu komoditas yang layak dikembangkan untuk mendukung program ketahanan pangan, karena komoditi ini dapat diolah menjadi 
berbagai macam produk makanan yang dapat dikonsumsi langsung sebagai pengganti beras (Tandi, dkk.,2011).

\section{Menurut data Badan Pusat Statistik} (BPS,2018), total produksi ubikayu di Indonesia pada tahun 2015 mencapai $21.801 .415 \mathrm{Mg}$ dengan luas lahan 949.916 ha setara dengan $22 \mathrm{Mg} \mathrm{ha}^{-1} \mathrm{th}^{-1}$. Sedangkan total produksi ubikayu di Provinsi Lampung pada tahun 2014 mencapai 8.034.016Mgdengan luas lahan 304.468 ha, sedangkan pada tahun 2015produksi ubikayu mencapai $7.387 .084 \mathrm{Mg}$ dengan luas lahan279.337 ha. Itu artinya produksi ubikayu di Provinsi Lampung mengalami penurunan produksi sebesar $646.932 \mathrm{Mg}$ dan lahan berkurang sebesar 25.131 ha.

Menurut Prasetyo dan Suriadikata (2006), kendala yang dihadapi dalam usaha meningkatkan produksi ubikayu di Provinsi Lampung yaitu dari jenis Tanah Ultisol. Beberapa kendala Tanah Ultisol sebagian besar berkembang dari batuan sedimen masam sehingga membuat reaksi tanah masam, kejenuhan basa rendah $(<35 \%)$, keracunan Al tinggi, kandungan hara makro rendah terutama $\mathrm{P}, \mathrm{K}, \mathrm{Ca}, \mathrm{Mg}$, dan $\mathrm{Na}$, kapasitas tukar kation (KTK) rendah, dan peka terhadap erosi. Salah satu cara paling efektif untuk mengatasi kendala yang dihadapi di tanah Ultisol adalah dengan cara mengintensifikasi lahan yang sudah ada agar hasil pertaniannya dapat terus meningkat. Salah satu cara mengintensifikasi lahan yang sudah ada adalah dengan pemupukan. Pemupukan dapat dilakukan dengan pemupukan organik, pemupukan anorganik, dan pemupukan kombinasi antara pupuk organik dan pupuk anorganik. Pemupukan dapat menambahkan unsur hara terhadap tanah yang kekurangan unsur hara menjadi kaya akan unsur hara.

Penelitian pengaruh pemberian pupuk Organonitrofos dan kombinasinya dengan pupuk kimia terhadap tanaman ubikayu telah dilakukan oleh Maulidia dilahan yang sama pada musim tanam pertama tahun 2013. Menurut Maulidia (2013), hasil percobaan lapang di musim tanam pertama bahwa pemberian kombinasi pupuk Organonitrofos dan pupuk kimia dengan dosis urea $100 \mathrm{~kg} \mathrm{ha}^{-1}, \mathrm{SP} 36100 \mathrm{~kg} \mathrm{ha}^{-1}, \mathrm{KCl}$ $200 \mathrm{~kg} \mathrm{ha}^{-1}$, Organonitrofos $1.000 \mathrm{~kg} \mathrm{ha}^{-1}$ mampu meningkatkan produksi umbi dan serapan hara NPK pada tanaman ubikayu.

Penelitian ini juga telah dilakukan telah dilakukan oleh Agsari dilahan yang sama pada musim tanam kedua tahun 2014. MenurutAgsari(2014), hasil percobaan lapangan di musim tanam kedua bahwa pemberian kombinasi pupuk Organonitrofos dan pupuk kimia dengan dosis urea $100 \mathrm{~kg} \mathrm{ha}^{-1}, \mathrm{SP} 36100 \mathrm{~kg} \mathrm{ha}^{-}$ ${ }^{1}, \mathrm{KCl} 200 \mathrm{~kg} \mathrm{ha}{ }^{-1}$, Organonitrofos $1.000 \mathrm{~kg} \mathrm{ha}^{-1}$ mampu meningkatkan produksi dan serapan hara $\mathrm{N}$ dan K pada tanaman ubikayu. Tujuan dari penelitian ini adalah untuk : 1) Mengetahui pengaruh pemberian pupuk Organonitrofos dan kombinasinya dengan pupuk anorganik yang tertinggi terhadap pertumbuhan, serapan hara NPK dan C, dan produksi tanaman ubikayu pada musim tanam ketiga; 2) Menetapkan dosis kombinasi pupuk Organonitrofos dengan pupuk anorganik yang paling efektif terhadap produksi bobot umbi basah, dan biomassa total tanaman ubikayu pada musim tanam ketiga. 


\section{BAHAN DAN METODE}

Penelitian ini merupakan satu musim dari penelitian jangka panjang tanaman ubi kayu. Pada musim tanam pertama penelitian ini dilakukan oleh Maulidia (2013) di Laboratorium Lapangan Terpadu Fakutas Pertanian Universitas Lampung pada 5²2' 10" LS dan $105^{\circ} 14^{\prime} 38^{\prime \prime}$ LU dan Laboratorium Kimia Tanah Fakultas Pertanian Universitas Lampung dari bulan Maret 2012 sampai dengan Febuari 2013. Penelitian pada musim tanam kedua dilakukan oleh Agsari (2014) di lahan yang sama dengan musim tanam pertama, dari bulan Maret 2013 hingga Febuari 2014. Penelitian pada musim ketiga ini juga dilaksanakan di lahan yang sama dengan musim tanam pertama dan musim tanam kedua. Penelitian ini dilakukan pada bulan November 2014 sampai dengan Agustus 2015.

Percobaan dilakukan dengan Rancangan Acak Lengkap. Percobaan tersebut terdiri dari 6 perlakuan (Tabel 1). Masing-masing perlakuan dilakukan sebanyak 3 ulangan. Terhadap data yang didapat kemudian akan dilakukan homogenitas data dengan uji bartlett, sifat aditifitas data dengan uji Tukey, analisis ragam, dan uji lanjut dengan BNT 5\%.Uji RAE untuk melihat dosis pupuk yang paling efektif.

\section{HASIL DAN PEMBAHASAN}

Hasil analisis kimia tanah awal dan akhir (Tabel 2), pada pemberian pupuk Organonitrofos dan kombinasinya menunjukkan N-total akhir mengalami kenaikan di setiap perlakuan dibandingkan $\mathrm{N}$-total awal. Menurut Firmansyah dan Sumarni, (2013), kuantitas pupuk $\mathrm{N}$ yang tinggi dan jumlah dosis pupuk $\mathrm{N}$ dapat mempengaruhi kandungan $\mathrm{N}$-total tanah. Hasil analisis kimia tanah awal dan akhir (Tabel 2), pada pemberian pupuk Organonitrofos dan kombinasinya menunjukkanP-tersedia, $\mathrm{K}$-dd, C-organik, dan $\mathrm{pH}$ tanah awal mengalami penurunan di setiap perlakuan dibandingkan P-tersedia, K-dd, C-organik, dan $\mathrm{pH}$ tanah akhir. Tanaman yang kekurangan hara $\mathrm{P}$ akan mengganggu proses metabolisme, menghambat proses pembentukan, dan pembesaran umbi (Tumewu, dkk., 2015). Pupuk K mampu meningkatkan pertumbuhan vegetatif tanaman ubikayu. Kalium berperan membantu proses fotosintesis yaitu pembentukkan senyawa organik baru yang diangkut ke organ tempat penimbunan yaitu umbibawang (Napitupulu dan Winarto, 2010). Hal ini sejalan dengan penelitian musim tanam pertama oleh Maulidia (2013) dan penelitian pada musim tanam kedua oleh Agsari (2014) dimana

Tabel 1. Perlakuan dosis pupuk yang digunakan

\begin{tabular}{ccccc}
\hline \multirow{2}{*}{ Perlakuan } & \multicolumn{3}{c}{ Dosis $\left(\mathrm{kg} \mathrm{ha}^{-1}\right)$} & Organonitrofos \\
\cline { 2 - 5 } & Urea & SP36 & KCl & - \\
\hline T1 (kontrol) & - & - & - & - \\
T2 & 200 & 300 & 400 & 500 \\
T3 & 150 & 200 & 300 & 1000 \\
T4 & 100 & 100 & 200 & 2000 \\
T5 & 50 & 50 & 100 & 5000 \\
T6 & - & - & - & \\
\hline
\end{tabular}


Tabel 2. Beberapa sifat kimia tanah awal dan akhir setelah aplikasi pupukOrganonitrofos dan kombinasinya dengan pupuk anorganikpada akhir musim tanam ketiga

\begin{tabular}{|c|c|c|c|c|c|c|c|}
\hline \multirow{2}{*}{\multicolumn{2}{|c|}{ Jenis Analisis }} & \multicolumn{6}{|c|}{ Perlakuan $\left(\mathrm{kgha}^{-1}\right)$} \\
\hline & & T1 & $\mathrm{T} 2$ & $\mathrm{~T} 3$ & $\mathrm{~T} 4$ & $\mathrm{~T} 5$ & T6 \\
\hline \multirow{2}{*}{$\begin{array}{c}\text { N-Total } \\
(\%)\end{array}$} & Awal & $0,09^{\mathrm{R}}$ & $0,15^{\mathrm{R}}$ & $0,15^{\mathrm{R}}$ & $0,15^{\mathrm{R}}$ & $0,17^{\mathrm{R}}$ & $0,15^{\mathrm{R}}$ \\
\hline & Akhir & $0,33^{\mathrm{s}}$ & $0,35^{\mathrm{s}}$ & $0,35^{\mathrm{s}}$ & $0,19^{K}$ & $0,30^{\mathrm{s}}$ & $0,33^{\mathrm{s}}$ \\
\hline \multirow{2}{*}{$\begin{array}{l}\text { P-Tersedia } \\
\text { (ppm) }\end{array}$} & Awal & $9,8^{\mathrm{s}}$ & $35,92^{\mathrm{SI}}$ & $24,28^{\mathrm{SI}}$ & $14,75^{1}$ & $11,05^{1}$ & $26,95^{\mathrm{SI}}$ \\
\hline & Akhir & $6,92^{\mathrm{SR}}$ & $16,25^{\mathrm{R}}$ & $8,78^{\mathrm{SR}}$ & $12,73^{\mathrm{SR}}$ & $7,53^{\mathrm{SR}}$ & $7,53^{\mathrm{SR}}$ \\
\hline \multirow{2}{*}{$\begin{array}{c}\text { K-dd } \\
\left(\mathrm{cmol} \mathrm{c} \mathrm{kg}^{-1}\right)\end{array}$} & Awal & $0,66^{\mathrm{T}}$ & $1,03^{\mathrm{ST}}$ & $1,04^{\mathrm{ST}}$ & $0,9^{\mathrm{T}}$ & $0,94^{\mathrm{T}}$ & $1,05^{\mathrm{ST}}$ \\
\hline & Akhir & $0,24^{\mathrm{R}}$ & $0,35^{\mathrm{R}}$ & $0,42^{\mathrm{s}}$ & $0,29^{\mathrm{R}}$ & $0,32^{\mathrm{R}}$ & $0,28^{\mathrm{R}}$ \\
\hline \multirow{2}{*}{$\begin{array}{c}\text { C-Organik } \\
(\%)\end{array}$} & Awal & $1,42^{\mathrm{K}}$ & $1,49^{\mathrm{K}}$ & $1,44^{\mathrm{K}}$ & $1,52^{\mathrm{K}}$ & $1,52^{\mathrm{K}}$ & $1,44^{\mathrm{K}}$ \\
\hline & Akhir & $1,24^{\mathrm{K}}$ & $1,31^{\mathrm{K}}$ & $1,11^{\mathrm{K}}$ & $1,11^{\mathrm{K}}$ & $1,18^{\mathrm{K}}$ & $1,47^{\mathrm{K}}$ \\
\hline \multirow{2}{*}{$\begin{array}{c}\mathrm{pH} \\
\left(\mathrm{H}_{2} \mathrm{O}\right)\end{array}$} & Awal & $6,4^{\mathrm{AM}}$ & $6,71^{\mathrm{N}}$ & $6,63^{\mathrm{N}}$ & $6,65^{\mathrm{N}}$ & $6,4^{\mathrm{AM}}$ & $6,91^{\mathrm{N}}$ \\
\hline & Akhir & $6,2^{\mathrm{AM}}$ & $5,88^{\mathrm{AM}}$ & $6,11^{\mathrm{AM}}$ & $6,2^{\mathrm{AM}}$ & $5,88^{\mathrm{AM}}$ & $5,79^{\mathrm{AM}}$ \\
\hline
\end{tabular}

Keterangan : T1 (kontrol), T2 (urea $200 \mathrm{~kg} \mathrm{ha}^{-1}$, SP36 $300 \mathrm{~kg} \mathrm{ha}^{-1}, \mathrm{KCl} 400 \mathrm{~kg} \mathrm{ha}^{-1}$ ), T3 (urea $150 \mathrm{~kg} \mathrm{ha}^{-1}$, SP36 $200 \mathrm{~kg} \mathrm{ha}^{-1}, \mathrm{KCl} 300 \mathrm{~kg} \mathrm{ha}^{-1}$, Organonitrofos $500 \mathrm{~kg} \mathrm{ha}^{-1}$ ), T4 (urea $100 \mathrm{~kg} \mathrm{ha}^{-1}$, SP36 $100 \mathrm{~kg}$ $\mathrm{ha}^{-1}, \mathrm{KCl} 200 \mathrm{~kg} \mathrm{ha}^{-1}$, Organonitrofos $1000 \mathrm{~kg} \mathrm{ha}^{-1}$ ), T5 (urea $50 \mathrm{~kg} \mathrm{ha}^{-1}$, SP36 $50 \mathrm{~kg} \mathrm{ha}^{-1}, \mathrm{KCl} 100$ $\mathrm{kg} \mathrm{ha}^{-1}$, Organonitrofos $2000 \mathrm{~kg} \mathrm{ha}^{-1}$ ), T6 (Organonitrofos $5000 \mathrm{~kg} \mathrm{ha}^{-1}$ ), AM (Agak Masam), N (Netral), R (Rendah), SR (Sangat Rendah), S (Sedang), T (Tinggi), ST (Sangat Tinggi) (Balai Penelitian Tanah, 2009).

pada analisis tanah akhir nilai C-organik mengalami penurunan. Kandungan C-organik rendah karena lahan yang dikelola secara intensif tanpa memperhatikan kelestarian kesehatan tanah. Penyebab salah satunya pelandaian produktivitas meskipun jenis dan dosis pupuk kimia ditingkatkan. Tanah yang subur memiliki kandungan bahan organik sekitar 3\%-5\% (Indriati, 2009).

Salah satu parameter yang digunakan untuk mengukur pertumbuhan vegetatiftanaman ubikayu pada percobaan ini adalah tinggi tanaman. Hasil analisis ragam menunjukkan bahwa tinggi tanaman ubikayu tidak berbeda nyata antar perlakuan yang artinya pemberian pupuk tidak berpengaruh nyata terhadap pertumbuhan vegetatif tanaman ubikayu (Gambar 1). Awalnya tidak terdapat perbedaan antara perlakuan pupuk Organonitrofos tunggal ataupun kombinasi dengan pupuk kimia terhadap tinggi tanaman ubikayu pada 4 MST (Gambar 1). Pada perlakuan pupuk Organonitrofos tunggal ataupun kombinasi dengan pupuk kimia tidak terdapat perbedaan antar perlakuan terhadap tinggi tanaman. Pada hasil analisis ragam pada 32 MST (minggu setelah tanam) menunjukkan perlakuan kedua menghasilkan tinggi tanaman yang tertinggi, tetapi tidak berbeda nyata dengan perlakuan lainnya hal ini diduga karena pada saat penelitian cuaca yang kurang mendukung (Tabel 3). Hal ini sejalan dengan penelitian pada musim tanam kedua tanaman ubikayu oleh Agsari (2014) bahwa tanaman ubikayu pada perlakuan kedua menghasilkan tinggi tanaman yang tertinggi namun tidak berbeda nyata pada setiap perlakuan. Sedangkan pada musim tanam pertama oleh Maulidia (2013) tanaman ubikayu pada perlakuaan keempat menghasilkan tinggi tanaman tertinggi. Hasil analisis ragam menunjukkan bahwa perlakuan yang diberikantidak mempengaruhi tinggi 
Tabel 3. Pengaruh kombinasi pupuk Orgnonitrofos dan pupuk kimia terhadaptinggi tanaman pada $32 \mathrm{MST}$

\begin{tabular}{cc}
\hline \multirow{2}{*}{ Perlakuan } & Tinggi Tanaman \\
\cline { 2 - 2 } & $\mathrm{cm}$ \\
\hline T1 & 295,33 \\
T2 & 349,87 \\
T3 & 331,87 \\
T4 & 333,93 \\
T5 & 295,33 \\
T6 & 314,93 \\
\hline Uji F & tn \\
\hline
\end{tabular}

Keterangan : T1 (kontrol), T2 (urea $200 \mathrm{~kg} \mathrm{ha}^{-1}$, SP36 $300 \mathrm{~kg} \mathrm{ha}^{-1}, \mathrm{KCl} 400 \mathrm{~kg} \mathrm{ha}^{-1}$ ), T3 (urea $150 \mathrm{~kg} \mathrm{ha}{ }^{-1}$, SP36 $200 \mathrm{~kg} \mathrm{ha}^{-1}, \mathrm{KCl} 300 \mathrm{~kg} \mathrm{ha}^{-1}$, Organonitrofos $500 \mathrm{~kg} \mathrm{ha}^{-1}$ ), T4 (urea $100 \mathrm{~kg} \mathrm{ha}^{-1}$, SP36 $100 \mathrm{~kg}$ $\mathrm{ha}^{-1}, \mathrm{KCl} 200 \mathrm{~kg} \mathrm{ha}^{-1}$, Organonitrofos $1000 \mathrm{~kg} \mathrm{ha}^{-1}$ ), T5 (urea $50 \mathrm{~kg} \mathrm{ha}^{-1}$, SP36 $50 \mathrm{~kg} \mathrm{ha}^{-1}, \mathrm{KCl} 100$ $\mathrm{kg} \mathrm{ha}^{-1}$, Organonitrofos $\left.2000 \mathrm{~kg} \mathrm{ha}^{-1}\right)$, T6 (Organonitrofos $5000 \mathrm{~kg} \mathrm{ha}^{-1}$ ), $\mathrm{tn}=$ tidak nyata.

Tabel 4. Pengaruh kombinasi pupuk Orgnonitrofos dan pupuk kimia terhadap bobot umbi basah, bobot kulit basah, dan bobot total umbi basah pada tanaman ubikayu

\begin{tabular}{|c|c|c|c|}
\hline \multirow{2}{*}{ Perlakuan } & Bobot Umbi Basah & Bobot Kulit Basah & Bobot Total Umbi Basah \\
\hline & \multicolumn{3}{|c|}{ 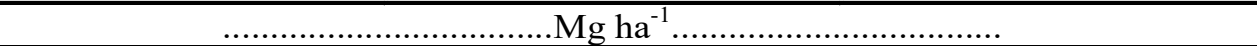 } \\
\hline T1 & $17,07 \mathrm{a}$ & $2,63 \mathrm{a}$ & $19,70 \mathrm{a}$ \\
\hline $\mathrm{T} 2$ & $66,41 \mathrm{~d}$ & $4,26 \mathrm{~b}$ & $70,67 \mathrm{~d}$ \\
\hline T3 & $33,60 \mathrm{c}$ & $3,88 \mathrm{~b}$ & $37,48 \mathrm{c}$ \\
\hline $\mathrm{T} 4$ & $67,73 \mathrm{~d}$ & $5,62 \mathrm{c}$ & $73,35 \mathrm{e}$ \\
\hline T5 & $27,73 \mathrm{~b}$ & $3,31 \mathrm{a}$ & $31,04 \mathrm{~b}$ \\
\hline T6 & $27,17 \mathrm{~b}$ & $3,26 \mathrm{a}$ & $30,43 \mathrm{~b}$ \\
\hline BNT 5\% & 2,05 & 0,80 & 3,12 \\
\hline
\end{tabular}

Keterangan: T1 (kontrol), T2 (urea $200 \mathrm{~kg} \mathrm{ha}^{-1}$, SP36 $300 \mathrm{~kg} \mathrm{ha}^{-1}, \mathrm{KCl} 400 \mathrm{~kg} \mathrm{ha}^{-1}$ ), T3 (urea $150 \mathrm{~kg} \mathrm{ha}^{-1}$, SP36 $200 \mathrm{~kg} \mathrm{ha}^{-1}, \mathrm{KCl} 300 \mathrm{~kg} \mathrm{ha}^{-1}$, Organonitrofos $500 \mathrm{~kg} \mathrm{ha}^{-1}$ ), T4 (urea $100 \mathrm{~kg} \mathrm{ha}^{-1}$, SP36 $100 \mathrm{~kg}$ $\mathrm{ha}^{-1}, \mathrm{KCl} 200 \mathrm{~kg} \mathrm{ha}^{-1}$, Organonitrofos $1000 \mathrm{~kg} \mathrm{ha}^{-1}$ ), T5 (urea $50 \mathrm{~kg} \mathrm{ha}^{-1}$, SP36 $50 \mathrm{~kg} \mathrm{ha}^{-1}, \mathrm{KCl} 100$ $\mathrm{kg} \mathrm{ha}^{-1}$, Organonitrofos $2000 \mathrm{~kg} \mathrm{ha}^{-1}$ ), T6 (Organonitrofos $5000 \mathrm{~kg} \mathrm{ha}^{-1}$ ). Angka yang diikuti dengan huruf yang sama pada kolom yang samatidak berbeda nyata pada uji BNT taraf 5\%.

tanaman. Hal ini serupa disampaikan oleh Herman, dkk., (2016) yang menyatakan bahwa tinggi tanaman ubi kayu tidak dipengaruhi oleh pemberian pupuk organik maupun anorganik, namun tinggi tanaman lebih dipengaruhi oleh faktor genotipe tanaman tersebut.

Berdasarkan hasil analisis ragam pemberian pupuk Organonitrofos dan pupuk kimia berbeda nyata antar perlakuan terhadap bobot umbi basah, dan bobot kulit basah. Hal ini diduga karena kandungan unsur hara pada tanah yangberbeda antar perlakuan, sehingga setiap perlakuan mengalami berbeda nyata antar perlakuan.Produksi umbi tanpa kulit basah, rata-rata bobot kulit basah, dan produksi total umbi tertinggi terdapat pada perlakuan keempat sebesar $67,73 \mathrm{Mg}$ ha $^{-1}$ disusul perlakuaan kedua sebesar $66,41 \mathrm{Mg} \mathrm{ha}^{-1}$, 5,62 $\mathrm{Mg} \mathrm{ha}^{-1}$, dan 73,35 $\mathrm{Mg} \mathrm{ha}^{-1}$. Sedangkan produksi umbi tanpa kulit basah dan bobot kulit basah terendah terdapat pada perlakuan pertama sebesar 17,07 $\mathrm{Mgha}^{-1}$ dan 2,63 $\mathrm{Mg} \mathrm{ha}^{-1}$ (Tabel 4). Hal ini sejalan dengan penelitian musim tanam pertama oleh Maulidia 
(2013) dan penelitian musim tanam kedua oleh Agsari (2014) bobot total umbi basah terdapat pada perlakuan keempat merupakan produksi tertinggi.

Berdasarkan hasil analisis ragam perlakuan dengan pupuk Organonitrofos dan pupuk kimia berbeda nyata antar perlakuan setelah dilakukan perlakuan terhadap bobot umbi kering, dan bobot batang kering. Sedangkan analisis ragam perlakuan dengan pupuk Organonitrofos dan pupuk kimia tidak berbeda nyata terhadap bobot daun kering, dan bobot kulit kering (Tabel 5). Pada hasil perhitungan data ratarata produksi umbi kering dan bobotkulit kering tertinggi terdapat pada perlakuan keempat menghasilkan bobot umb i kering sebesar 9,03 $\mathrm{Mg} \mathrm{ha}^{-1}$ dan bobot kulit kering sebesar 0,93 $\mathrm{Mg} \mathrm{ha}^{-1}$ (Tabel 5). Pada bobot kulit kering tidak berbeda nyata disebabkan karena kandungan air pada bobot daun basah tidak mampu meningkatkan bobot pada saat dioven, sehingga bobot setelah dioven akan menunjukkan tidak ada perbedaan yang signifikan antar perlakuan. Pada penelitian musim tanam pertama dan musim tanam kedua pada tanaman ubikayu oleh Maulidia (2013) dan Agsari (2014) menunjukkan bahwa hasil bobot total tertinggi pada perlakuan keempat.

Berdasarkan hasil analisis ragam perlakuan dengan pupuk Organonitrofos dan pupuk kimia tidak berbeda nyata antar perlakuan setelah dilakukan perlakuan terhadap bobot kulitkering, dan bobot daun kering. Pada hasil perhitungan rata-rata bobot kulit kering dan bobot daun kering tidak berbeda antar perlakuan. Hasil uji BNT yang telah dilakukan pada batang keringdan daun kering tertinggi terdapat perlakuan keempat menghasilkan bobot batang kering sebesar 8,41 $\mathrm{Mg} \mathrm{ha}^{-1}$ dan bobot daun kering sebesar 1,09 $\mathrm{Mg} \mathrm{ha}^{-1}$ (Tabel 5). Pada bobot daun kering tidak berbeda nyata disebabkan karena kandungan air pada

Tabel 5. Pengaruh kombiinasi pupuk Orgnonitrofos dan pupuk kimia terhadapbobot umbi kering, batang kering, kulit kering,daun kering, dan totalbiomassa kering pada tanaman ubikayu

\begin{tabular}{|c|c|c|c|c|c|}
\hline \multirow[t]{2}{*}{ Perlakuan } & $\begin{array}{c}\text { Bobot } \\
\text { Umbi } \\
\text { Kering }\end{array}$ & $\begin{array}{l}\text { Bobot } \\
\text { Kulit } \\
\text { kering }\end{array}$ & $\begin{array}{l}\text { Bobot } \\
\text { Batang } \\
\text { Kering }\end{array}$ & $\begin{array}{l}\text { Bobot } \\
\text { Daun } \\
\text { kering }\end{array}$ & $\begin{array}{c}\text { Total } \\
\text { biomassa }\end{array}$ \\
\hline & & & $\mathrm{Mg} \mathrm{ha}^{-1} \ldots$ & ….......... & \\
\hline $\mathrm{T} 1$ & $5,87 \mathrm{a}$ & 0,83 & $4,87 \mathrm{a}$ & 0,98 & $12,55 \mathrm{a}$ \\
\hline $\mathrm{T} 2$ & $8,95 \mathrm{c}$ & 0,88 & $6,16 \mathrm{~b}$ & 1,06 & $17,06 \mathrm{c}$ \\
\hline T3 & $8,08 \mathrm{bc}$ & 0,87 & $5,54 \mathrm{ab}$ & 1,01 & $15,49 \mathrm{~b}$ \\
\hline $\mathrm{T} 4$ & $9,03 \mathrm{c}$ & 0,93 & $8,41 \mathrm{c}$ & 1,09 & $19,46 \mathrm{~d}$ \\
\hline $\mathrm{T} 5$ & $7,32 \mathrm{~b}$ & 0,86 & $5,44 \mathrm{a}$ & 1,00 & $14,63 \mathrm{~b}$ \\
\hline T6 & $6,01 \mathrm{a}$ & 0,86 & $5,41 \mathrm{a}$ & 1,00 & $13,27 \mathrm{a}$ \\
\hline Uji F & $* *$ & th & $* *$ & $\operatorname{tn}$ & $* *$ \\
\hline BN T $5 \%$ & 1,02 & - & 0,76 & - & 1,35 \\
\hline
\end{tabular}

Keterangan : T1 (kontrol), T2 (urea $200 \mathrm{~kg} \mathrm{ha}^{-1}$, SP36 $300 \mathrm{~kg} \mathrm{ha}^{-1}, \mathrm{KCl} 400 \mathrm{~kg} \mathrm{ha}^{-1}$ ), T3 (urea $150 \mathrm{~kg} \mathrm{ha}{ }^{-1}$, SP36 $200 \mathrm{~kg} \mathrm{ha}^{-1}, \mathrm{KCl} 300 \mathrm{~kg} \mathrm{ha}^{-1}$, Organonitrofos $500 \mathrm{~kg} \mathrm{ha}^{-1}$ ), T4 (urea $100 \mathrm{~kg} \mathrm{ha}^{-1}$, SP36 $100 \mathrm{~kg} \mathrm{ha}^{-1}$, $\mathrm{KCl} 200 \mathrm{~kg} \mathrm{ha}^{-1}$, Organonitrofos $1000 \mathrm{~kg} \mathrm{ha}^{-1}$ ), T5 (urea $50 \mathrm{~kg} \mathrm{ha}^{-1}, \mathrm{SP} 3650 \mathrm{~kg} \mathrm{ha}^{-1}, \mathrm{KCl} 100 \mathrm{~kg}$ $\mathrm{ha}^{-1}$, Organonitrofos $2000 \mathrm{~kg} \mathrm{ha}^{-1}$ ), T6 (Organonitrofos $5000 \mathrm{~kg} \mathrm{ha}^{-1}$ ). Angka yang diikuti dengan huruf yang sama pada kolom yang sama tidak berbeda nyata pada uji BNT taraf 5\%. 
bobot daun basah tidak berbeda-beda, sehingga bobot setelah di oven akan menunjukkan tidak ada perbedaan yang signifikan antar perlakuan.Pada total biomassa menunjukkan tertinggi pada perlakuan keempat sebesar 19,46 $\mathrm{Mgha}^{-1}$ (Tabel 5). Hal ini sejalan dengan penelitian pada musim tanam pertama dan musim tanam kedua pada tanaman ubikayu oleh Maulidia(2013) dan Agsari (2014) menunjukkan bahwa hasil bobot total brangkasan tertinggi pada perlakuan keempat.
Hasil analisis ragam menunjukkan bahwa pemupukan Organonitrofos dan pupuk kimia berpengaruh nyata terhadap panen hara $\mathrm{N}, \mathrm{P}, \mathrm{K}$, dan C pada umbi dan batang. Hasil uji BNT yang telah dilakukan pada umbi dan batang menunjukkan panen hara $\mathrm{N}, \mathrm{P}, \mathrm{K}$, dan $\mathrm{C}$ tertinggi terdapat pada perlakuan keempat masing-masing memiiki $\mathrm{N}$ sebesar $6,49 \mathrm{~kg}$ ha $^{-1}$ dan 90,21 kg ha-1 (Tabel 6), P sebesar 12,76 kg $\mathrm{ha}^{-1}$ dan 16,95 $\mathrm{kg} \mathrm{ha}^{-1}$ (Tabel 7), K sebesar 15,17 kg

Tabel 6. Pengaruh kombinasi pupuk Orgnonitrofos dan pupuk kimia terhadappanen hara N pada umbi, batang, daun, kulit, dan total tanaman ubikayu

\begin{tabular}{|c|c|c|c|c|c|}
\hline \multirow{2}{*}{ Perlakuan } & \multicolumn{5}{|c|}{ Panen hara $\mathrm{N}\left(\mathrm{kg} \mathrm{ha}^{-1}\right)$} \\
\hline & Umbi & Batang & Daun & Kulit & To tal \\
\hline $\mathrm{T} 1$ & $1,65 \mathrm{a}$ & 2,27 a & $21,34 \mathrm{a}$ & $1,55 \mathrm{a}$ & $27,90 \mathrm{a}$ \\
\hline $\mathrm{T} 2$ & $4,57 \mathrm{~d}$ & $51,77 \mathrm{e}$ & $32,53 \mathrm{~b}$ & $4,12 \mathrm{~d}$ & $109,32 \mathrm{e}$ \\
\hline T3 & $3,36 \mathrm{c}$ & $49,08 \mathrm{~d}$ & $28,67 \mathrm{~b}$ & $3,65 \mathrm{c}$ & $92,72 \mathrm{~d}$ \\
\hline $\mathrm{T} 4$ & $6,49 \mathrm{e}$ & $90,21 \mathrm{f}$ & $42,69 \mathrm{c}$ & $7,37 \mathrm{e}$ & $182,43 \mathrm{f}$ \\
\hline $\mathrm{T} 5$ & $3,69 \mathrm{c}$ & $12,70 \mathrm{c}$ & $23,92 \mathrm{a}$ & $3,62 \mathrm{c}$ & $53,90 \mathrm{c}$ \\
\hline T6 & $2,36 \mathrm{~b}$ & $10,09 \mathrm{~b}$ & $22,83 \mathrm{a}$ & $2,00 \mathrm{~b}$ & $40,54 \mathrm{~b}$ \\
\hline Uji F & $* *$ & $* *$ & $* *$ & $* *$ & $* *$ \\
\hline BN T 5\% & 0,36 & 0,56 & 3,17 & 0,12 & 10,06 \\
\hline
\end{tabular}

Keterangan : T1 (kontrol), T2 (urea $200 \mathrm{~kg} \mathrm{ha}^{-1}$, SP36 $300 \mathrm{~kg} \mathrm{ha}^{-1}, \mathrm{KCl} 400 \mathrm{~kg} \mathrm{ha}^{-1}$ ), T3 (urea $150 \mathrm{~kg} \mathrm{ha}^{-1}$, SP36 $200 \mathrm{~kg} \mathrm{ha}^{-1}, \mathrm{KCl} 300 \mathrm{~kg} \mathrm{ha}^{-1}$, Organonitrofos $500 \mathrm{~kg} \mathrm{ha}^{-1}$ ), T4 (urea $100 \mathrm{~kg} \mathrm{ha}^{-1}$, SP36 $100 \mathrm{~kg} \mathrm{ha}^{-1}$, $\mathrm{KCl} 200 \mathrm{~kg} \mathrm{ha}^{-1}$, Organonitrofos $1000 \mathrm{~kg} \mathrm{ha}^{-1}$ ), T5 (urea $50 \mathrm{~kg} \mathrm{ha}^{-1}$, SP36 $50 \mathrm{~kg} \mathrm{ha}^{-1}, \mathrm{KCl} 100 \mathrm{~kg}$ $\mathrm{ha}^{-1}$, Organonitrofos $\left.2000 \mathrm{~kg} \mathrm{ha}^{-1}\right)$, T6 (Organonitrofos $\left.5000 \mathrm{~kg} \mathrm{ha}^{-1}\right)$. Angka yang diikuti dengan huruf yang sama pada kolom yang sama tidak berbeda nyata pada uji BNT taraf $5 \%$.

Tabel 7. Pengaruh kombinasi pupuk Orgnonitrofos dan pupuk kimia terhadap panen hara P pada umbi, batang, daun, kulit, dan total tanaman ubikayu

\begin{tabular}{|c|c|c|c|c|c|}
\hline \multirow{2}{*}{ Perlakuan } & \multicolumn{5}{|c|}{ Panen hara $\mathrm{P}\left(\mathrm{kg} \mathrm{ha}^{-1}\right)$} \\
\hline & $\mathrm{Umbi}$ & Batang & Daun & Kulit & To ta 1 \\
\hline $\mathrm{T} 1$ & $7,43 \mathrm{a}$ & $10,34 \mathrm{a}$ & $20,82 \mathrm{a}$ & $1,86 \mathrm{a}$ & $40,45 \mathrm{a}$ \\
\hline $\mathrm{T} 2$ & $11,38 \mathrm{~d}$ & $14,31 \mathrm{c}$ & $36,85 \mathrm{~d}$ & $4,26 \mathrm{~d}$ & $66,81 \mathrm{~d}$ \\
\hline T3 & $10,06 \mathrm{c}$ & $13,54 \mathrm{~b}$ & $30,88 \mathrm{c}$ & $3,19 \mathrm{c}$ & $57,68 \mathrm{c}$ \\
\hline $\mathrm{T} 4$ & $12,76 \mathrm{e}$ & $16,95 \mathrm{~d}$ & $41,18 \mathrm{e}$ & $4,48 \mathrm{~d}$ & $75,37 \mathrm{e}$ \\
\hline T5 & $8,99 \mathrm{~b}$ & $12,85 \mathrm{~b}$ & $28,07 \mathrm{~b}$ & $2,35 \mathrm{~b}$ & $52,27 \mathrm{~b}$ \\
\hline T6 & $7,77 \mathrm{a}$ & $11,27 \mathrm{a}$ & $30,04 \mathrm{~b}$ & $2,12 \mathrm{a}$ & $47,72 \mathrm{~b}$ \\
\hline Uji F & $* *$ & $* *$ & $* *$ & $* *$ & $* *$ \\
\hline $\mathrm{BN} \mathrm{T} 5 \%$ & 0,93 & 1,21 & 3,48 & 0,39 & 4,59 \\
\hline
\end{tabular}

Keterangan : T1 (kontrol), T2 (urea $200 \mathrm{~kg} \mathrm{ha}^{-1}$, SP36 $300 \mathrm{~kg} \mathrm{ha}^{-1}, \mathrm{KCl} 400 \mathrm{~kg} \mathrm{ha}^{-1}$ ), T3 (urea $150 \mathrm{~kg} \mathrm{ha}^{-1}$, SP36 $200 \mathrm{~kg} \mathrm{ha}^{-1}, \mathrm{KCl} 300 \mathrm{~kg} \mathrm{ha}^{-1}$, Organonitrofos $500 \mathrm{~kg} \mathrm{ha}^{-1}$ ), T4 (urea $100 \mathrm{~kg} \mathrm{ha}^{-1}$, SP36 $100 \mathrm{~kg} \mathrm{ha}^{-1}$, $\mathrm{KCl} 200 \mathrm{~kg} \mathrm{ha}^{-1}$, Organonitrofos $1000 \mathrm{~kg} \mathrm{ha}^{-1}$ ), T5 (urea $50 \mathrm{~kg} \mathrm{ha}^{-1}$, SP36 $50 \mathrm{~kg} \mathrm{ha}^{-1}, \mathrm{KCl} 100 \mathrm{~kg}$ $\mathrm{ha}^{-1}$, Organonitrofos $2000 \mathrm{~kg} \mathrm{ha}^{-1}$ ), T6 (Organonitrofos $5000 \mathrm{~kg} \mathrm{ha}^{-1}$ ). Angka yang diikuti dengan huruf yang sama pada kolom yang sama tidak berbeda nyata pada uji BNT taraf 5\%. 
ha $^{-1}$ dan 11,95 kg ha-1 (Tabel 8), C sebesar 70,29 kg ha $^{-1}$ dan 59,91 kg ha-1 ${ }^{-1}$ tetapi untuk umbi tidak berbeda nyata dengan perlakuan kedua (Tabel 9). Hal ini sejalan dengan penelitian musim tanam pertama oleh Maulidia (2013) dan penelitian musim tanam kedua oleh Agsari (2014) serapan hara $\mathrm{N}$ dan $\mathrm{K}$ tertinggi terdapat pada perlakuan keempat, sedangkan serapan hara P pada musim tanam pertama tertinggi pada perlakuan keempat danmusim tanam kedua tertinggi pada perlakuan kedua.

Hasil analisis ragam pada panenhara $N, P, K$, dan $\mathrm{C}$ pada kulit umbi dan daun menunjukkan berbeda nyata antar perlakuan. Hasil uji BNT yang telah dilakukan pada kulit umbi dan daun menunjukkan panen hara $\mathrm{N}, \mathrm{P}, \mathrm{K}$, dan $\mathrm{C}$ tertinggi terdapat pada perlakuan keempat masing-masing memiliki $\mathrm{N}$ sebesar 7,37 $\mathrm{kg} \mathrm{ha}^{-1}$ dan 42,69 $\mathrm{kg} \mathrm{ha}^{-1}$ (Tabel 6), P sebesar 4,48 $\mathrm{kg} \mathrm{ha}^{-1}$ dan 41,18 $\mathrm{kg} \mathrm{ha}^{-1}$ (Tabel 7), K sebesar 8,62 $\mathrm{kg} \mathrm{ha}^{-1}$ dan 2,46 $\mathrm{kg} \mathrm{ha}^{-1}$ (Tabel 8), C sebesar 19,93 $\mathrm{kg} \mathrm{ha}^{-1}$ dan 23,60 $\mathrm{kg} \mathrm{ha}^{-1}$ (Tabel 9).Hasil panen hara total $\mathrm{N}, \mathrm{P}, \mathrm{K}$, dan $\mathrm{C}$ tertinggi terdapat pada perlakuan keempatmasing-masing $\mathrm{N}$ sebesar 182,43 $\mathrm{kg} \mathrm{ha}^{-1}$ (Tabel 6), P sebesar 75,37 $\mathrm{kg} \mathrm{ha}^{-1}$ (Tabel 7), K sebesar 38,20 $\mathrm{kg} \mathrm{ha}^{-1}$ (Tabel 8), C sebesar 173,73 kg $\mathrm{ha}^{-1}$ (Tabel 9). Hal ini sejalan dengan penelitian musim tanam pertama oleh Maulidia (2013) dan penelitian musim tanam kedua oleh Agsari (2014) serapan hara $\mathrm{N}$ dan K tertinggi terdapat pada perlakuan keempat, sedangkan serapan hara $\mathrm{P}$ pada musim tanam pertama tertinggi pada perlakuan keempat dan musim tanam kedua tertinggi pada perlakuan kedua.

Tanaman yang kekurangan unsur hara $\mathrm{P}$ akan mengganggu proses metabolisme dalam tanaman. Pupuk P sangat berperan dalam meningkatkan jumlah umbi, karena sangat diperlukan dalam pembentukkan akar tanaman. Sedangkan peran fosfat dalam proses fisiologis tanaman adalah sebagai penyedia energi yang diperlukan untuk proses metabolisme dan reaksi biosentesis (Tumewu, dkk., 2015).

Tabel 8. Pengaruh kombinasi pupuk Orgnonitrofos dan pupuk kimia terhadappanen hara K pada umbi, batang, daun, kulit, dan total tanaman ubikayu

\begin{tabular}{|c|c|c|c|c|c|}
\hline \multirow{2}{*}{ Perlakuan } & \multicolumn{5}{|c|}{ Panen hara $\mathrm{K}\left(\mathrm{kg} \mathrm{ha}^{-1}\right)$} \\
\hline & Umbi & Batang & Daun & Kulit & To tal \\
\hline T1 & $3,36 \mathrm{a}$ & $4,49 \mathrm{a}$ & $1,62 \mathrm{a}$ & $1,79 \mathrm{a}$ & $11,28 \mathrm{a}$ \\
\hline $\mathrm{T} 2$ & $9,36 \mathrm{c}$ & $7,02 \mathrm{~b}$ & $2,25 \mathrm{~b}$ & $4,44 \mathrm{e}$ & $23,06 \mathrm{~d}$ \\
\hline T3 & $5,98 \mathrm{~b}$ & $6,48 b$ & $2,23 \mathrm{~b}$ & $4,20 \mathrm{~d}$ & $18,88 \mathrm{c}$ \\
\hline T4 & $15,17 \mathrm{~d}$ & $11,95 \mathrm{c}$ & $2,46 \mathrm{c}$ & $8,62 \mathrm{f}$ & $38,20 \mathrm{e}$ \\
\hline T5 & $5,05 \mathrm{~b}$ & $5,05 \mathrm{a}$ & $2,03 \mathrm{~b}$ & $2,45 \mathrm{c}$ & $14,58 \mathrm{~b}$ \\
\hline T6 & $3,44 \mathrm{a}$ & $4,52 \mathrm{a}$ & $1,70 \mathrm{a}$ & $1,96 \mathrm{~b}$ & $11,59 \mathrm{a}$ \\
\hline $\mathrm{Uji} F$ & $* *$ & $* *$ & $* *$ & $* *$ & $* *$ \\
\hline $\mathrm{BNT} 5 \%$ & 1,27 & 1,24 & 0,23 & 0,12 & 1,95 \\
\hline
\end{tabular}

Keterangan : T1 (kontrol), T2 (urea $200 \mathrm{~kg} \mathrm{ha}^{-1}$, SP36 $300 \mathrm{~kg} \mathrm{ha}^{-1}, \mathrm{KCl} 400 \mathrm{~kg} \mathrm{ha}^{-1}$ ), T3 (urea $150 \mathrm{~kg} \mathrm{ha}^{-1}$, SP36 $200 \mathrm{~kg} \mathrm{ha}^{-1}, \mathrm{KCl} 300 \mathrm{~kg} \mathrm{ha}^{-1}$, Organonitrofos $500 \mathrm{~kg} \mathrm{ha}^{-1}$ ), T4 (urea $100 \mathrm{~kg} \mathrm{ha}^{-1}$, SP36 $100 \mathrm{~kg} \mathrm{ha}^{-1}$, $\mathrm{KCl} 200 \mathrm{~kg} \mathrm{ha}^{-1}$, Organonitrofos $1000 \mathrm{~kg} \mathrm{ha}^{-1}$ ), T5 (urea $50 \mathrm{~kg} \mathrm{ha}^{-1}$, SP36 $50 \mathrm{~kg} \mathrm{ha}^{-1}, \mathrm{KCl} 100 \mathrm{~kg}$ $\mathrm{ha}^{-1}$, Organonitrofos $2000 \mathrm{~kg} \mathrm{ha}^{-1}$ ), T6 (Organonitrofos $5000 \mathrm{~kg} \mathrm{ha}^{-1}$ ). Angka yang diikuti dengan huruf yang sama pada kolom yang sama tidak berbeda nyata pada uji BNT taraf 5\%. 
Tabel 9. Pengaruh kombinasi pupuk Orgnonitrofos dan pupuk kimia terhadap C terangkut pada umbi, batang, daun, kulit, dan total tanama nubikayu

\begin{tabular}{cccccc}
\hline \multirow{2}{*}{ Perlakuan } & \multicolumn{5}{c}{ C terangkut tanaman $\left(\mathrm{kg} \mathrm{ha}^{-1}\right)$} \\
\cline { 2 - 6 } & Umbi & Batang & Daun & Kulit & $16,24 \mathrm{a}$ \\
T1 & $42,45 \mathrm{a}$ & $39,31 \mathrm{a}$ & $17,66 \mathrm{a}$ & $115,65 \mathrm{a}$ \\
T2 & $65,47 \mathrm{c}$ & $50,74 \mathrm{c}$ & $21,72 \mathrm{c}$ & $19,87 \mathrm{c}$ & $157,80 \mathrm{c}$ \\
T3 & $60,74 \mathrm{~b}$ & $49,65 \mathrm{c}$ & $20,02 \mathrm{~b}$ & $19,03 \mathrm{~b}$ & $149,44 \mathrm{~b}$ \\
T4 & $70,29 \mathrm{c}$ & $59,91 \mathrm{~d}$ & $23,60 \mathrm{~d}$ & $19,93 \mathrm{c}$ & $173,73 \mathrm{~d}$ \\
T5 & $59,32 \mathrm{~b}$ & $44,98 \mathrm{~b}$ & $20,00 \mathrm{~b}$ & $17,90 \mathrm{~b}$ & $142,20 \mathrm{~b}$ \\
T6 & $43,61 \mathrm{a}$ & $43,06 \mathrm{a}$ & $17,98 \mathrm{a}$ & $17,17 \mathrm{a}$ & $121,81 \mathrm{a}$ \\
\hline Uji F & $* *$ & $* *$ & $* *$ & $* *$ & 1,16 \\
\hline BNT 5\% & 5,60 & 4,39 & 1,16 & 8,38 \\
\hline KN
\end{tabular}

Keterangan : T1 (kontrol), T2 (urea $200 \mathrm{~kg} \mathrm{ha}^{-1}$, SP36 $300 \mathrm{~kg} \mathrm{ha}^{-1}, \mathrm{KCl} 400 \mathrm{~kg} \mathrm{ha}^{-1}$ ), T3 (urea $150 \mathrm{~kg} \mathrm{ha}^{-1}$, SP36 $200 \mathrm{~kg} \mathrm{ha}^{-1}, \mathrm{KCl} 300 \mathrm{~kg} \mathrm{ha}^{-1}$, Organonitrofos $500 \mathrm{~kg} \mathrm{ha}^{-1}$ ), T4 (urea $100 \mathrm{~kg} \mathrm{ha}^{-1}$, SP36 $100 \mathrm{~kg} \mathrm{ha}^{-1}$, $\mathrm{KCl} 200 \mathrm{~kg} \mathrm{ha}^{-1}$, Organonitrofos $1000 \mathrm{~kg} \mathrm{ha}^{-1}$ ), T5 (urea $50 \mathrm{~kg} \mathrm{ha}^{-1}$, SP36 $50 \mathrm{~kg} \mathrm{ha}^{-1}, \mathrm{KCl} 100 \mathrm{~kg}$ $\mathrm{ha}^{-1}$, Organonitrofos $2000 \mathrm{~kg} \mathrm{ha}^{-1}$ ), T6 (Organonitrofos $5000 \mathrm{~kg} \mathrm{ha}^{-1}$ ). Angka yang diikuti dengan huruf yang sama pada kolom yang sama tidak berbeda nyata pada uji BNT taraf 5\%.

Tabel 10. Indeks relative Agronomic Effectiveness (RAE) pada produksi bobotumbi basah, dan biomassa total

\begin{tabular}{ccc}
\hline perlakuan & $\begin{array}{c}\text { RAE Bobot } \\
\text { umbi basah }(\%)\end{array}$ & $\begin{array}{c}\text { RAE Biomassa } \\
\text { total }(\%)\end{array}$ \\
\hline T1 & 0 & 0 \\
T2 & 100 & 100 \\
T3 & 34,88 & 65,19 \\
T4 & 105,25 & 153,22 \\
T5 & 22,25 & 46,12 \\
T6 & 21,04 & 15,96 \\
\hline
\end{tabular}

Keterangan : T1 (kontrol), T2 (urea $200 \mathrm{~kg} \mathrm{ha}^{-1}$, SP36 $300 \mathrm{~kg} \mathrm{ha}^{-1}, \mathrm{KCl} 400 \mathrm{~kg} \mathrm{ha}^{-1}$ ), T3 (urea $150 \mathrm{~kg} \mathrm{ha}{ }^{-1}, \mathrm{SP} 36$ $200 \mathrm{~kg} \mathrm{ha}^{-1}, \mathrm{KCl} 300 \mathrm{~kg} \mathrm{ha}^{-1}$, Organonitrofos $500 \mathrm{~kg} \mathrm{ha}^{-1}$ ), T4 (urea $100 \mathrm{~kg} \mathrm{ha}^{-1}$, SP36 $100 \mathrm{~kg} \mathrm{ha}^{-1}$, KCl $200 \mathrm{~kg} \mathrm{ha}^{-1}$, Organonitrofos $1000 \mathrm{~kg} \mathrm{ha}^{-1}$ ), T5 (urea $50 \mathrm{~kg} \mathrm{ha}^{-1}$, SP36 $50 \mathrm{~kg} \mathrm{ha}^{-1}, \mathrm{KCl} 100 \mathrm{~kg}$ $\mathrm{ha}^{-1}$, Organonitrofos $\left.2000 \mathrm{~kg} \mathrm{ha}^{-1}\right)$, T6 (Organonitrofos $\left.5000 \mathrm{~kg} \mathrm{ha}^{-1}\right)$.

RAE merupakan perbandingan hasil (biomass) penggunaan suatu pupuk dengan penggunaan dari pupuk rekomendasi. Pupuk rekomendasi yang digunakan pada penelitian ini terdapat pada perlakuan kedua.Berdasarkan analisis Relative Agronomic Effectiveness(RAE) terdapat pada penelitian ini, perlakuan keempat menghasilkan efektivitas pada biomass total sebesar $153 \%$ sedangkan pada bobot umbi basah sebesar 105\%. RAE perlakuan keempat lebih besar dibandingkan dengan penggunaan pupuk standar pada perlakuan kedua. Sedangkan pada dosis pupuk tunggal pupuk Organonitrofos hanya memiliki nilai RAE pada biomass total sebesar $15 \%$ dan RAE bobot umbi basah sebesar 21\% (Tabel 10).

\section{KESIMPULAN}

Kesimpulan yang didapat berdasarkan penelitian yang telah dilakukan adalah:

1. Pertumbuhan, produksi, dan panen haraNPK dan C tertinggi terdapat pada perlakuan keempat dengan 
dosis pupuk urea $100 \mathrm{~kg} \mathrm{ha}^{-1}$, SP36 $100 \mathrm{~kg} \mathrm{ha}^{-1}$, KCl $200 \mathrm{~kg} \mathrm{ha}^{-1}$, Organonitrofos $1000 \mathrm{~kg} \mathrm{ha}^{-1}$, dibandingkan dengan perlakuan lainnya.

2.Dosis pupuk Organonitrofos dan pupuk anorganikyang paling efektif meningkatkan bobot umbi basah dan biomass total terdapat adanya dosis pupuk urea $100 \mathrm{~kg} \mathrm{ha}^{-1}, \mathrm{SP} 36100 \mathrm{~kg} \mathrm{ha}^{-1}, \mathrm{KCl}$ $200 \mathrm{~kg} \mathrm{ha}^{-1}$, Organonitrofos $1000 \mathrm{~kg} \mathrm{ha}^{-1}$ sebesar $105 \%$ bobot umbi dan $153 \%$ biomassa total.

\section{DAFTAR PUSTAKA}

Agsari, D. 2014. Uji efektivitas Pupuk Organonitrofos dan kombinasinya dengan Pupuk Kimia terhadap Pertumbuhan, Serapan Hara dan Produksi Tanaman Ubikayu (Manihot esculenta Crantz) di musim tanam kedua pada Tanah Ultisol Gedung Meneng. Skripsi. Universitas Lampung. Bandar Lampung. $122 \mathrm{hlm}$.

BPS. 2018. Produksi Ubi Kayu di Indonesia. http:/ bps.go.id. Diakses tanggal 7 Juli 2018.

Firmansyah, I., dan Sumarni, N. 2013. Pengaruh Dosis Pupuk N dan Varietas Terhadap pH Tanah, N-Total, Serapan N, dan Hasil Umbi Bawang (Allium ascalonicum L) pada Tanah Entisols Brebes Jawa Tengah. J. Hort. 23 (4): 358364.

Herman., D. I. Roslim., dan I. Y. Fitriani. Respon Genotipe Ubi Kayu (Manihot Esculent Crantz) Terhadap Dosis Pupuk Kandang Kotoran Sapi Taluk Kuantan. J. Dinamika Pertanian. 32 (2): 135-142.
Indriati, T. R. 2009. Pengaruh Dosis Pupuk Organik dan Populasi Tanaman terhadap Pertumbuhan serta Hasil Tumpang Sari Kedelai (Glycine max L) dan jagung (Zea mays L). Tesis. Surakarta: Universitas Sebelas Maret. $77 \mathrm{hlm}$.

Maulidia, O. 2013. Uji Efektivitas Kombinasi Pupuk Organonitrofos dan Pupuk Anorganik terhadap Pertumbuhan, Serapan Hara dan Produksi Tanaman Ubikayu. Skripsi. Universitas Lampung. Bandar Lampung. 84 hlm.

Napitupulu, D., dan L. Winarto. 2010. Pengaruh Pemberian Pupuk N dan K terhadap Pertumbuhan dan Produksi Bawang Merah. $J$. Hort. 20 (1): 27-35.

Prasetyo, B. H, dan D. A. Suryadikata. 2006. Karakteristi, Potensi, dan Teknologi Pengelolaan Tanah Ultisol untuk Pengembangan Pertanian Lahan Kering di Indonesia.Jurnal Litbang Pertanian. 25 (2): 39-47.

Tandi, I., P. M. Malen, Samaria, dan Ramli. 2011. Analisis Agribisnis Ubi Kayu Studi Kasus di Kampung Macuan, Distrik Masni, Kabupaten Manokwari. Jurnal Agrisistem. 7 (2): 63-70.

Tumewu, P., C.P. Paruntu, dan T. D. Sondakh. 2015. Hasil Ubi Kayu (Mannihot esculenta Crantz) terhadap Perbedaan Jenis Pupuk. Jurnal LPPM Bidang Sains dan Teknologi. 2 (2): 16-27. 